\title{
Efficient phosphorus application strategies for increased crop production in sub-Saharan West Africa
}

\author{
Andreas Buerkert ${ }^{\mathrm{a}, *}$, André Bationo ${ }^{\mathrm{b}}$, Hans-Peter Piepho ${ }^{\mathrm{a}}$ \\ ${ }^{a}$ Institute of Crop Science, University of Kassel, Steinstr. 19, D-37213 Witzenhausen, Germany \\ ${ }^{\mathrm{b}}$ TSBF-UNESCO, United Nations Complex, Gigiri, P.O. Box 30592, Nairobi, Kenya \\ Received 15 December 2000; received in revised form 17 April 2001; accepted 25 April 2001
}

\begin{abstract}
Comparable data are lacking from the range of environments found in sub-Saharan West Africa to draw more general conclusions about the relative merits of locally available rockphosphate (RockP) in alleviating phosphorus (P) constraints to crop growth. To fill this gap, a multi-factorial field experiment was conducted over 4 years at eight locations in Niger, Burkina Faso and Togo. These ranged in annual rainfall from 510 to $1300 \mathrm{~mm}$. Crops grown were pearl millet (Pennisetum glaucum L.), sorghum (Sorghum bicolor (L.) Moench) and maize (Zea mays L.) either continuously or in rotation with cowpea (Vigna unguiculata Walp.) and groundnut (Arachis hypogaea L.). Crops were subjected to six P fertiliser treatments comprising RockP and soluble $\mathrm{P}$ at different rates and combined with 0 and $60 \mathrm{~kg} \mathrm{~N} \mathrm{ha}^{-1}$. For legumes, time trend analyses showed $\mathrm{P}$ induced total dry matter (TDM) increases between 28 and $72 \%$ only with groundnut. Similarly, rotation-induced raises in cereal TDM compared to cereal monoculture were only observed with groundnut. For cereals, at the same rate of application, RockP was comparable to single superphosphate (SSP) only at two millet sites with topsoil $\mathrm{pH}-\mathrm{KCl}<4.2$ and annual average rainfall $>600 \mathrm{~mm}$. Across the eight sites NPK placement at $0.4 \mathrm{~g} \mathrm{P}$ per hill raised average cereal yields between 26 and $220 \%$. This was confirmed in 119 on-farm trials revealing P placement as a promising strategy to overcome P deficiency as the regionally most growth limiting nutrient constraint to cereals. (C) 2001 Elsevier Science B.V. All rights reserved.
\end{abstract}

Keywords: Crop rotation; Fertiliser placement; Legumes; Millet; Rockphosphate; Soil fertility

\section{Introduction}

Low levels of soil phosphorus $(\mathrm{P})$ and nitrogen $(\mathrm{N})$ are the major constraints to crop growth on nutrientdepleted sandy soils of sub-Saharan West Africa above $400 \mathrm{~mm}$ annual rainfall (Bationo et al., 1992, 1993, 1998a,b; Poulain et al., 1974). The low surface coverage with plants enhances the deleterious effects of wind and water erosion on topsoil productivity and further contributes to negative nutrient balances at the

\footnotetext{
* Corresponding author. Fax: +49-554-298-1228.

E-mail address: buerkert@wiz.uni-kassel.de (A. Buerkert).
}

watershed level. These are reported to reach $15 \mathrm{~kg} \mathrm{~N}$, $2 \mathrm{~kg} \mathrm{P}$ and $15 \mathrm{~kg} \mathrm{~K} \mathrm{ha}^{-1} \mathrm{yr}^{-1}$ for the predominantly agro-pastoral land-use systems of this region (Buerkert and Hiernaux, 1998; Stoorvogel and Smaling, 1994). Application of soluble $P$ fertilisers and locally available rockphosphates (RockPs) can enhance organic carbon (Corg) fixation in the agro-ecosystem and improve crop yields (McClellan and Notholt, 1986; Roesch and Pichot, 1985). On a strongly acid soil with $600 \mathrm{~mm}$ average rainfall RockP application was almost as effective as single superphosphate (SSP) in increasing yields of pearl millet (Pennisetum glaucum L., Bationo et al., 1990). Nevertheless, the 
application of mineral fertilisers regardless of their type, to rainfed staple crops in Sudano-Sahelian West Africa remains below $5 \mathrm{~kg} \mathrm{ha}^{-1} \mathrm{yr}^{-1}$ (van Reuler and Prins, 1993). In an effort to increase fertiliser use efficiency and to reduce investment costs to cash-poor, subsistence-oriented farmers, $\mathrm{P}$ placement has been advocated as an effective technique to increase crop growth (Bationo et al., 1998a,b; Buerkert and Hiernaux, 1998). Localised fertiliser application seems a promising strategy in this environment where planting densities for hand-planted millet under on-farm conditions average at 5000 hills ha $^{-1}$ (McIntire, 1986). In previous studies seed placement of $13 \mathrm{~kg} \mathrm{Pha}^{-1}$ as SSP resulted in only limited yield gains compared to broadcast applications of the same amount (Christianson et al., 1990). This was attributed to rapid water depletion in the dense root zone around the placed fertiliser. Subsequent work with seed coating equivalent to $100 \mathrm{~g} \mathrm{P} \mathrm{ha}^{-1}$ showed large early placement effects on millet growth that, however, decreased to a mere $10 \%$ yield advantage at final harvest (Rebafka et al., 1993a). The purpose of this paper was to draw more general conclusions about the effectiveness of broadcast and placed application of soluble $\mathrm{P}$ and RockPs in alleviating $\mathrm{P}$ deficiency to cereals under the low-input conditions of sub-Saharan West Africa. To this end a multi-year experiment was conducted on benchmark sites in the Sahelian, Sudanian and Guinean zone of this region. Using time trend analysis, the results of this experiment were summarised and interpreted over the 4 years of its duration and in view of the large differences in site-specific edaphic, climatic and plant species-dependent properties.

\section{Materials and methods}

\subsection{Multi-factorial experiment}

\subsubsection{Sites}

From 1995 to 1998 multi-factorial trials were conducted under rainfed conditions on Psammentic Paleustalfs in the Sahelian zone of Niger at Banizoumbou $\left(13^{\circ} 31^{\prime} \mathrm{N}, 2^{\circ} 39^{\prime} \mathrm{E}\right)$, Sadoré $\left(13^{\circ} 14^{\prime} \mathrm{N}\right.$, $\left.2^{\circ} 17^{\prime} \mathrm{E}\right)$, Kara Bedji $\left(13^{\circ} 15^{\prime} \mathrm{N}, 2^{\circ} 32^{\prime} \mathrm{E}\right)$ and Goberi $\left(12^{\circ} 58^{\prime} \mathrm{N}, 2^{\circ} 50^{\prime} \mathrm{E}\right)$, on an Arenic Kandiustalf in the Sudanian zone of Niger at Gaya-Bengou $\left(11^{\circ} 59^{\prime} \mathrm{N}\right.$, $3^{\circ} 32^{\prime} \mathrm{E}$ ) and on a Haplustalf in the Sudanian zone of Burkina Faso at Fada $\left(11^{\circ} 59^{\prime} \mathrm{N}, 0^{\circ} 19^{\prime} \mathrm{E}\right)$. From 1996 to 1999 the experiment was extended to the northern Guinean zone of Togo on an isohyperthermic Plinthic Kanhaplustult at Koukombo $\left(10^{\circ} 17^{\prime} \mathrm{N}, 0^{\circ} 23^{\prime} \mathrm{E}\right)$ and an isohyperthermic Plinthustalf at Kaboli $\left(8^{\circ} 45^{\prime} \mathrm{N}\right.$, $1^{\circ} 35^{\prime} \mathrm{E}$ ). The chosen sites covered a wide range of edaphic and climatic conditions with a single growing season of 4-6 months (Table 1). Soils in the Sahelian zone were derived from eroded and re-deposited sand dunes, ranged in $\mathrm{pH}-\mathrm{KCl}$ between 4.1 and 4.5 , had

Table 1

Mean annual precipitation and initial soil chemical parameters at 0-0.2 m depth for eight sites in West Africa in May 1995 (data from Buerkert et al., 2000)

\begin{tabular}{|c|c|c|c|c|c|c|c|c|c|c|}
\hline Site & $\begin{array}{l}\text { Precipitation }^{a} \\
(\mathrm{~mm})\end{array}$ & $\mathrm{pH}^{\mathrm{b}}$ & $\begin{array}{l}\text { Clay } \\
\left(\mathrm{g} \mathrm{kg}^{-1}\right)\end{array}$ & $\begin{array}{l}\text { Corg } \\
\left(\mathrm{mg} \mathrm{kg}^{-1}\right)\end{array}$ & $\begin{array}{l}\text { P-Bray I } \\
\left(\mathrm{mg} \mathrm{kg}^{-1}\right)\end{array}$ & $\begin{array}{l}\text { P-water }{ }^{\mathrm{c}} \\
\left(\mu \mathrm{g} \mathrm{kg}^{-1}\right)\end{array}$ & $\begin{array}{l}\mathrm{Ca}^{2+} \\
\left(\mathrm{cmol} \mathrm{kg}^{-1}\right)\end{array}$ & $\begin{array}{l}\mathrm{CEC}^{\mathrm{d}} \\
\left(\mathrm{cmol} \mathrm{kg}^{-1}\right)\end{array}$ & $\begin{array}{l}\mathrm{BS}^{\mathrm{e}} \\
(\%)\end{array}$ & $\begin{array}{l}\mathrm{N}_{\min } \\
\left(\mathrm{mg} \mathrm{kg}^{-1}\right)\end{array}$ \\
\hline Banizoumbou & 510 & 4.4 & 50 & 1.50 & 1.5 & 300 & 0.4 & 0.8 & 74 & 5 \\
\hline Sadoré & 560 & 4.5 & 30 & 2.26 & 2.8 & 440 & 0.4 & 1.1 & 86 & n.a. ${ }^{\mathrm{f}}$ \\
\hline Kara Bedji & 590 & 4.2 & 40 & 1.57 & 1.9 & 130 & 0.2 & 0.8 & 56 & 4 \\
\hline Goberi & 600 & 4.1 & 30 & 1.55 & 1.7 & 280 & 0.2 & 0.8 & 50 & 2 \\
\hline Gaya & 800 & 4.2 & 130 & 3.30 & 2.5 & 140 & 0.4 & 1.3 & 66 & 9 \\
\hline Fada & 850 & 5.4 & 150 & 5.20 & 1.3 & 320 & 1.8 & 2.8 & 99 & 3 \\
\hline Koukombo & 1100 & 5.6 & 50 & 3.67 & 2.0 & 1100 & 1.3 & 1.9 & 97 & 12 \\
\hline Kaboli & 1300 & 4.7 & 160 & 6.46 & 3.8 & 1250 & 1.3 & 3.3 & 71 & 18 \\
\hline
\end{tabular}

\footnotetext{
${ }^{\text {a }}$ Average annual rainfall for $5-10$ years.

${ }^{\mathrm{b}} \mathrm{pH}$ in $0.01 \mathrm{M} \mathrm{KCl}(1: 2.5)$.

${ }^{\mathrm{c}} \mathrm{P}$-water determined after Sissingh (1971) but with incubation time reduced to $5 \mathrm{~min}$ at a soil:water ratio of 1:10.

${ }^{\mathrm{d}}$ Effective cation exchange capacity.

${ }^{\mathrm{e}}$ Base saturation.

${ }^{\mathrm{f}}$ Not available.
} 
between 30 and $50 \mathrm{~g} \mathrm{~kg}^{-1}$ clay, varied in Corg content between 1.5 and $2.3 \mathrm{mg} \mathrm{kg}^{-1}$, were poorly aggregated and showed only little evidence of macro-organisms. Soils in the Sudano-Guinean zone, in contrast, were much higher in $\mathrm{pH}$, had about three times more clay and Corg and appeared well aggregated (Table 1). With increasing amounts of total annual rainfall, these heavier soils were also characterised by clay and silica movement and showed strong evidence of termite activity. At all sites, trials were laid out in a split-plot design with completely randomised mainplots of $10 \times 10 \mathrm{~m}^{2}$ size.

\subsubsection{Mainplots}

Six $\mathrm{P}$ fertiliser treatments and two levels of $\mathrm{N}$ were factorially combined and replicated twice in each trial. Crop residues (CR) were broadcast in all plots at traditional farmers' level $\left(500 \mathrm{~kg} \mathrm{ha}^{-1}\right)$ in January of each year, the middle of the dry season. Phosphorus treatments consisted of (i) a control without $\mathrm{P}(\mathrm{PO})$; (ii) annual broadcast $\mathrm{P}$ applied at $13 \mathrm{~kg} \mathrm{ha}^{-1}$ as SSP (SSP13); (iii) broadcast $\mathrm{P}$ applied once for 3 years as high quality ('soft') Tahoua RockP at $39 \mathrm{~kg} \mathrm{ha}^{-1}$ (TRockP39); (iv) annual hill-placement of $4 \mathrm{~kg} \mathrm{Pha}^{-1}\left(\mathrm{P}_{\text {placed }}\right)$ as ground SSP in 1995 and 1996 and as ground NPK fertiliser (15-15-15) in 1997, 1998 and 1999; (v) TRockP39 combined with $\mathrm{P} 4$ placed and (vi) broadcast $\mathrm{P}$ applied once for 10 years as TRockP at $130 \mathrm{~kg} \mathrm{P} \mathrm{ha}^{-1}$ (TRockP130) combined with $\mathrm{P}_{\text {placed. }}$ Despite generally higher TDM production in the wetter zones and differences in the cereal species sown, P levels were kept constant to facilitate the comparison of treatment effects on crop growth and soil properties across environments. To study residual effects of broadcast $\mathrm{P}$ application, in the fourth year annual $P$ was reapplied only in treatment $\mathrm{P} 4{ }_{\text {placed. }}$. Due to space constraints at Sadoré, $\mathrm{P}$ was only applied at the first four levels. Nitrogen, applied as calcium ammonium nitrate (CAN) at 0 and $60 \mathrm{~kg} \mathrm{~N} \mathrm{ha}^{-1}$ was split into three equal applications, which were made after emergence, at thinning and at booting.

\subsubsection{Subplots}

The following four cropping systems were randomly assigned as $5 \mathrm{~m} \times 5 \mathrm{~m}$ wide subplots to each of the 32 mainplots: continuous cereal, both phases of the cereal/legume rotation and a cereal-legume intercrop. Of these treatments, only the first three were considered in the analyses reported here, because the cereal-legume intercrop followed local practices and changed over years. In the Sahelian and the Sudanian zone of Niger, the cereal sown was millet at 10000 hills ha $^{-1}$, in Burkina Faso sorghum was sown at 40000 hills ha $^{-1}$ and in Togo maize at 53330 hills ha $^{-1}$. Typically hills comprised three plants for millet and one plant for sorghum and maize. The legume sown at all sites in Niger was cowpea at 40000 hills ha $^{-1}$; at Fada, Koukombo and Kaboli groundnut was sown at 55550 hills ha $^{-1}$. The choice of the legume species depended on farmers' preference in the predominant local cropping system. Legumes were sown after the rainy season was well established, usually 20-30 days after the cereal. At harvest, the hills of each plot, with the exception of border rows, were cut and dry weight of grain, heads and remaining straw were determined at $65^{\circ} \mathrm{C}$ to compute total dry matter (TDM). Plant TDM rather than grain yield was chosen as output variable because (i) this parameter was less affected by rainfall distribution, pest and diseases and (ii) both straw and grain are of similarly high value within the integrated crop-livestock systems of the region. Further details about the crop husbandry were reported by Bagayoko et al. (2000b).

\subsubsection{Statistical analysis}

Each plot in an experiment provided a time series of 4 years. Simple linear regressions of crop TDM versus year were used to assess trends on a plot basis. Regression slopes were then subjected to analysis of variance. This procedure, also known as two-stage or derived variable analysis, appropriately handles autocorrelation in longitudinal data (Diggle et al., 1994).

In cereal legume-rotation plots, cereal yield data were only produced every second year. For these plots, cereal data from both subplots (different phases) within a mainplot were merged to obtain a full time series of cereal yield data for the rotation over 4 years. These were denoted as Y1, Y2, Y3 and Y4. The same approach to obtain 4 years of data was followed in legumes. The regression slope for a time series (SLOPE in $\mathrm{kg} \mathrm{ha}^{-1} \mathrm{yr}^{-1}$ ) was used as a response variable in a subsequent analysis of variance for each of the eight trials. Regression slopes were also 
computed when an observation in the series was missing. Since only very few data were missing, no adjustment was deemed necessary. Subsequently, the regression was used to derive two variables, that is the predicted yield in the first and the fourth year (P1 and P4). These predictions were used to graphically display regression trend lines. Yield data were pooled across $\mathrm{N}$ and cropping systems whenever these factors did not show statistically significant effects $(P<0.05)$.

The analysis of a trial for the derived variable SLOPE proceeded in two steps. First, the full model was fitted using the GLM procedure of the SAS System (SAS Institute, 1990). Non-significant terms $(P>0.05)$ were dropped, subject to the marginality requirement that lower order effects were retained despite non-significance if a corresponding higherorder term was significant (Nelder, 1994). Since P fertiliser treatment was the main factor of interest, the main effect for this factor was generally retained even if non-significant. In the second step, the reduced model was used for computing treatment means. The model selected for the derived variable SLOPE was used also to analyse the derived traits P1 and P4. The main purpose of these analyses was to generate graphical displays showing the time trend for different factor levels. A scatter was displayed around the trend lines with points given by least square means for the original data (Y1, Y2, Y3 and Y4) based on separate analyses for the 4 years using the same linear model as that selected for SLOPE. All graphs contain least significant differences $\left(\mathrm{LSD}_{0.05}\right)$ for the vertical distance between regression lines in the first and fourth year. This LSD is based on the relevant standard error of a difference from the REML analysis of the derived variables $\mathrm{P} 1$ and $\mathrm{P} 4$. Multiple mean comparisons were conducted and displayed as described by Piepho (2000a,b).

For cereals the full and reduced models were formulated with the following explanatory variables (for legumes there was no cropping system factor).

\subsubsection{Variables}

$\mathrm{P}=$ mineral $\mathrm{P}$ rate $(0=\mathrm{P} 0 ; 1=\mathrm{SSP} 13 ; 2=$ TRock$\mathrm{P} 39 ; 3=\mathrm{TRockP} 39+\mathrm{P} 4_{\text {placed }} ; 4=\mathrm{P}_{\text {placed }} ;$ and $5=$ TRockP130 $\left.+\mathrm{P} 4_{\text {placed }}\right), \mathrm{N}=$ mineral $\mathrm{N}$ rate $(0=\mathrm{N} 0$; $1=$ N60), SYSTEM $=$ cropping system $(1=$ continuous cereal $2=$ rotation cereal $/$ legume) .

\subsection{On-farm testing of $P$ placement}

\subsubsection{Treatments and sites}

In 1998 a total of 120 Nigerien farmers in the Maradi, Dosso and Say regions were co-operating to test P placement effects under on-farm conditions. Each farmer was asked to choose a piece of millet land and to divide it into two parts similar in size, cropping history and average natural productivity. One part served as a control without mineral fertiliser (P0), the other received $0.4 \mathrm{~g} \mathrm{P}$ applied as $6 \mathrm{~g}$ of ground NPK (15-15-15) fertiliser placed together with the seed in each hill at sowing ( $\left.\mathrm{P} 4_{\text {placed }}\right)$. At 10000 hills ha ${ }^{-1}$, this was equivalent to $4 \mathrm{~kg} \mathrm{P} \mathrm{ha}^{-1}$, but farmers' densities averaged to about half of that. Farmers were allowed to use the cultivar, sowing density and management practices, such as crop residue or manure application and number of weeding operations, of their choice provided that both plots were treated the same. In 1999 similar on-farm trials were conducted with different farmers in the region of Say, southern Niger, which included a third treatment consisting of placed diammonium phosphate (18-460 , DAP) application at $0.4 \mathrm{~g} P$ per hill. This treatment was added because prices per unit of $\mathrm{P}$ applied were more advantageous than for NPK; it also allowed to examine the relative role of $\mathrm{N}$ versus $\mathrm{P}$ in the observed fertiliser placement effects under farmers' conditions.

\subsubsection{Data and risk analysis}

In both years local collaborators recorded grain yields for each farmer by sampling at least $100 \mathrm{~m}^{2}$ in both plots. After discarding data from farmers who did not follow the agreed upon rules, the final data comprised 91 pairs of grain yields in 1998 and 28 sets in 1999 coming from fields varying in size between 400 and $5000 \mathrm{~m}^{2}$. For each year, these data were sorted according to the magnitude of the control plot yields and presented as a scatter plot.

Both data sets were also used to assess the relative risk of the $\mathrm{P} 4_{\text {placed }}$ treatment compared to farmers' current practice, the unfertilised treatment $\mathrm{P} 0$. To this end, for each farm the yield mean (MEAN), defined as $\left[\frac{1}{2}\left(\mathrm{P} 4_{\text {placed }}+\mathrm{P} 0\right)\right]$, was computed as a soil productivity index. Risk analysis was based on net returns per treatment. Since the main interest was in treatment differences, only the return and cost factors differing among treatments were taken into account. These 
were: grain yield $\left(\mathrm{kg} \mathrm{ha}^{-1}\right) ;$ grain price $=60$ $\mathrm{FCFA}^{1} \mathrm{~kg}^{-1}$; fertiliser price $=150 \mathrm{FCFA} \mathrm{kg}{ }^{-1}$; amount of fertiliser $=30 \mathrm{~kg} \mathrm{NPK} \mathrm{ha}^{-1}$; child wage for placed $\mathrm{P}$ application at sowing $=500$ FCFA per day; time for placed $\mathrm{P}$ application $=1.7$ days $\mathrm{ha}^{-1}$. This information was used to compute DIFF $(=$ net return $\mathrm{P} 4$ placed - net return $\mathrm{P} 0) . \quad$ A quadratic regression of DIFF on MEAN was performed to assess whether superiority of a treatment depended on soil fertility. Since a preliminary analysis revealed no year effects (results not shown), data from control and NPK plots of both years were pooled. Assuming normally distributed errors around the regression line, the risk that net return $\mathrm{P} 4$ placed $<$ net return $\mathrm{P} 0$ (RISK) was computed for each value of MEAN. The RISK was plotted against the MEAN, with 95\% confidence limits computed as described by Piepho (2000c).

\section{Results}

\subsection{Multi-factorial experiment}

\subsubsection{Legumes}

Neither N nor P significantly affected legume TDM development over time at any site (Table 2). At some sites cowpea TDM tended to decline consistently over the duration of the experiment, however, none of the regression slopes was significantly different from zero. After 4 years and averaged across both $\mathrm{N}$ levels, trend lines predicted a $28 \%$ greater groundnut TDM for SSP13 compared to the control (P0) at Fada and a $72 \%$ increase at both Koukombo and Kaboli. At the two Guinean sites similar increases in groundnut TDM were predicted for TRockP39 $+\mathrm{P} 4$ placed (data not shown).

\subsubsection{Cereals}

3.1.2.1. Treatment effects on time trends. In contrast to Sadoré, Gaya and Fada where millet TDM time trends under both cropping systems were unaffected by $\mathrm{P}$ and $\mathrm{N}$ application, $\mathrm{N}$ significantly increased millet TDM trends at Banizoumbou and Goberi (Table 2). Nitrogen effects were even more

\footnotetext{
${ }^{1} 100$ FCFA, the local currency unit $=1$ French Franc or about 0.15 US\$.
}

prominent for maize at the two Guinean sites where large interactions between $\mathrm{N}$ and cropping system were observed. In contrast, $\mathrm{P}$ effects on time trends in cereal TDM were detectable only at the Sahelian sites of Banizoumbou, Kara Bedji and Goberi and were negligible at any of the sites in the SudanoGuinean zone. Phosphorus effects appeared to be independent of cropping system. Cropping system effects on cereal TDM were highly significant for all rotations with groundnut but there were no cropping system effects for cowpea (Table 2).

\subsubsection{Phosphorus application in the Sahelian zone.} Compared to the control, $\mathrm{P} 4$ placed was remarkably effective in shifting trend lines upward at two out of three trial sites. At Banizoumbou, the driest site of the experiment, the expression of $\mathrm{P}$ effects appeared to be largely governed by N (Fig. 1A and B). Millet TDM in plots that received no $\mathrm{P}$ but $\mathrm{N}$, tended to increase over time (Fig. 1B). After 4 years TRockP39 $+\mathrm{P} 4_{\text {placed }}$ yielded significantly greater than the unfertilised control independent of $\mathrm{N}$ application. Nitrogen application led to final average increases in the predicted millet biomass by $1410 \mathrm{~kg} \mathrm{ha}^{-1}$ across $P$ levels.

At Sadoré, millet TDM without P strongly declined over time at both levels of $\mathrm{N}$ and cropping system. This decline was weaker, though not reversed, with either of the four similarly effective $\mathrm{P}$ application strategies tested at this site (Fig. 2). At Kara Bedji, control yield remained constant over time. TRockP39 was the least effective at this site, whereas $\mathrm{P} 4_{\text {placed }}$ alone led to predicted TDM increases by $81 \%$ and in combination with TRockP39 or TRockP130 by 99 and $133 \%$ for the fourth year, respectively (Fig. 3). At Goberi, the relative ranking of $\mathrm{P}$ time trends strongly depended on $\mathrm{N}$, which was also reflected in a highly significant $\mathrm{N} \times \mathrm{P}$ interaction (Table 2). Particularly noteworthy was the large increase in the yield enhancing effects of TRockP39 with added N (Fig. 4). Overall, however, $\mathrm{N}$-induced increases in millet TDM were much smaller than these at Banizoumbou (Table 2 and Fig. 1).

\subsubsection{Phosphorus application in the Sudanian} zone. At Gaya, millet TDM levels were overall much lower than at any of the Sahelian sites. Regardless of $\mathrm{N}$ or cropping system, slopes of time 
Table 2

$P$-values for $F$-tests of treatment effects on time trends (slopes) in a multi-factorial experiment conducted over 4 years with nitrogen (N) and phosphorus (P) applied to monoculture legumes and cereals grown in two cropping systems (SYSTEM; monoculture and cereal/legume rotation) at eight sites in West Africa

\begin{tabular}{|c|c|c|c|c|c|c|c|c|c|c|}
\hline \multirow[t]{3}{*}{ Site } & \multirow[t]{3}{*}{ Precipitation $^{\mathrm{a}}$} & \multicolumn{9}{|c|}{ Treatment factor } \\
\hline & & \multicolumn{3}{|c|}{ Legumes $^{\mathrm{b}}$} & \multicolumn{6}{|c|}{ Cereals ${ }^{c}$} \\
\hline & & $\mathrm{N}$ & $\mathrm{P}$ & $\mathrm{N} \times \mathrm{P}$ & $\mathrm{N}$ & $\mathrm{P}$ & $\mathrm{N} \times \mathrm{P}$ & SYSTEM & $\mathrm{N} \times \mathrm{SYSTEM}$ & $\mathrm{P} \times \mathrm{SYSTEM}$ \\
\hline Banizoumbou & 510 & 0.9531 & 0.0977 & 0.7367 & 0.0001 & 0.0034 & 0.1968 & 0.0610 & 0.5534 & 0.9556 \\
\hline Sadoré & 560 & 0.3973 & 0.3468 & 0.6481 & 0.7187 & 0.1129 & 0.3941 & 0.1072 & 0.2238 & 0.7943 \\
\hline Kara Bedji & 590 & 0.0923 & 0.6130 & 0.7368 & 0.1368 & 0.0197 & 0.4501 & 0.4130 & 0.7026 & 0.3203 \\
\hline Goberi & 600 & 0.6199 & 0.0827 & 0.1328 & 0.0501 & 0.0002 & 0.0065 & 0.1287 & 0.7217 & 0.4545 \\
\hline Gaya & 800 & 0.9128 & 0.2824 & 0.9555 & 0.4947 & 0.1714 & 0.5462 & 0.3307 & 0.1621 & 0.5106 \\
\hline Fada & 850 & 0.4952 & 0.1835 & 0.1008 & 0.4240 & 0.3315 & 0.7556 & 0.0225 & 0.3537 & 0.7601 \\
\hline Koukombo & 1100 & 0.1824 & 0.5973 & 0.5796 & 0.0001 & 0.2398 & 0.6200 & 0.0004 & 0.0003 & 0.3828 \\
\hline Kaboli & 1300 & 0.5840 & 0.7230 & 0.9419 & 0.0001 & 0.2485 & 0.2298 & 0.0001 & 0.0001 & 0.5204 \\
\hline
\end{tabular}

${ }^{a}$ Average annual rainfall for 5-10 years.

${ }^{\mathrm{b}}$ Cowpea (Vigna unguiculata Walp.) at Banizoumbou, Sadoré, Kara Bedji, Goberi and Gaya; and groundnut (Arachis hypogaea L.) at Fada, Koukombo and Kaboli.

${ }^{\mathrm{c}}$ Millet (Pennisetum glaucum L.) at Banizoumbou, Sadoré, Kara Bedji, Goberi and Gaya; sorghum (Sorghum bicolor L. Moench) at Fada; and maize (Zea mays L.) at Koukombo and Kaboli.

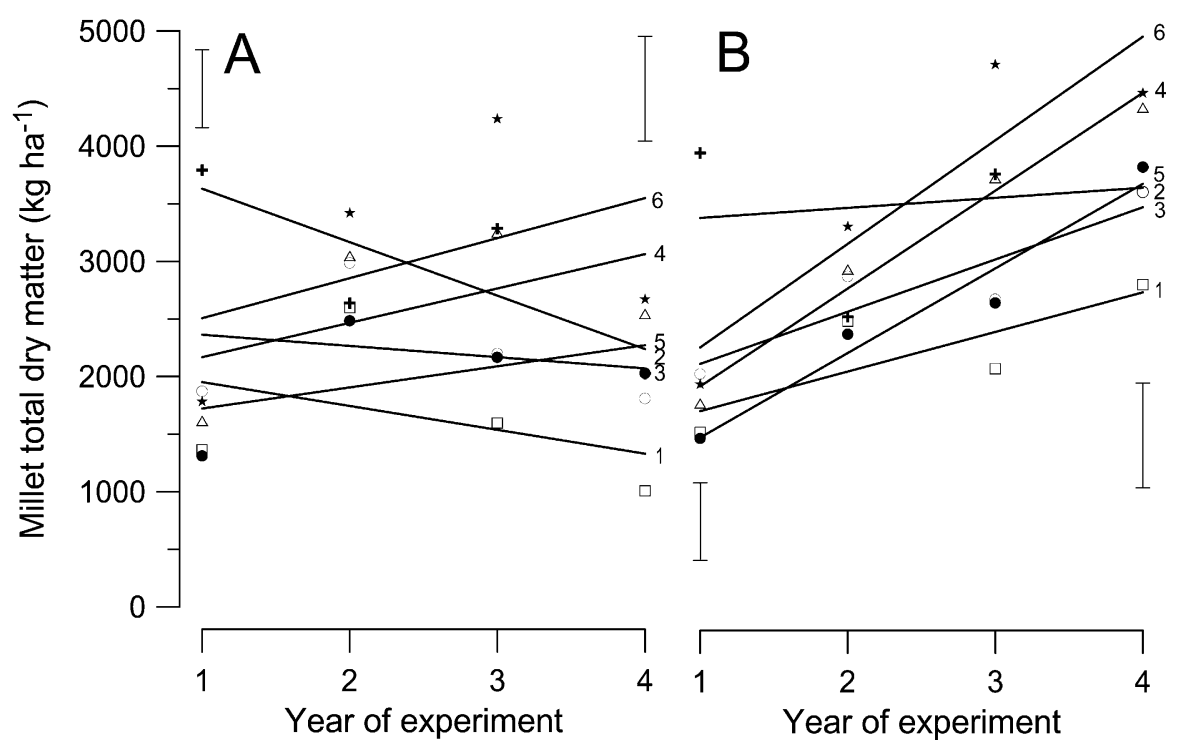

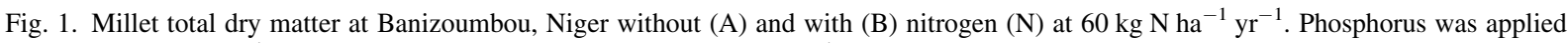
at $(1=\square) 0 \mathrm{~kg} \mathrm{Pha}^{-1}$ (control); $(2=+)$ annually as SSP at $13 \mathrm{~kg} \mathrm{Pha}^{-1},(3=\bigcirc)$ as broadcast 'soft' Tahoua rock phosphate (TRockP ) at $39 \mathrm{~kg} \mathrm{P} \mathrm{ha}^{-1}$ once for 3 years; $(4=\triangle)$ as TRockP at $39 \mathrm{~kg} \mathrm{P} \mathrm{ha}^{-1}$ once every 3 years combined with annually hill-placed SSP or NPK at $4 \mathrm{~kg} \mathrm{Pha}^{-1} ;(5=\mathbf{0})$ annually as hill-placed; SSP or NPK at $4 \mathrm{~kg} \mathrm{P} \mathrm{ha}^{-1}$ alone and $(6=\star)$ as TRockP at $130 \mathrm{~kg} \mathrm{P}^{-1}$ once every 10 years combined with annually hill-placed SSP or NPK at $4 \mathrm{~kg} \mathrm{P} \mathrm{ha}^{-1}$. The scatter data are least squares means based on yearwise analyses using the same linear mixed model for the description of multi-factorial treatment effects as for the time trend (SLOPE) variable. Trend lines were obtained by connecting predictions in year $1(\mathrm{P} 1)$ and year $4(\mathrm{P} 4)$. Vertical bars show least significant differences $\left(\mathrm{LSD}_{0.05}\right)$ comparing predicted means for cropping systems in year 1 (P1) and in year 4 (P4), respectively. 


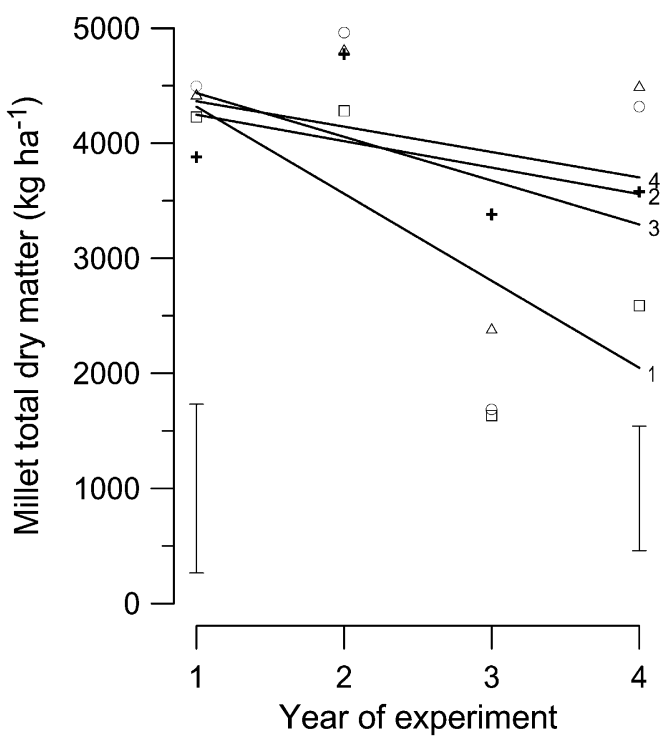

Fig. 2. Millet total dry matter at Sadoré, Niger averaged for nitrogen applied at 0 and $60 \mathrm{~kg} \mathrm{~N} \mathrm{ha}^{-1} \mathrm{yr}^{-1}$. For explanation of symbols and numbers see Fig. 1.

trends tended to be more negative for higher levels of applied $\mathrm{P}$ than for the unfertilised control, (Fig. 5). At Fada, the large rotation-induced increases in sorghum TDM were consistent across all levels of applied $\mathrm{N}$

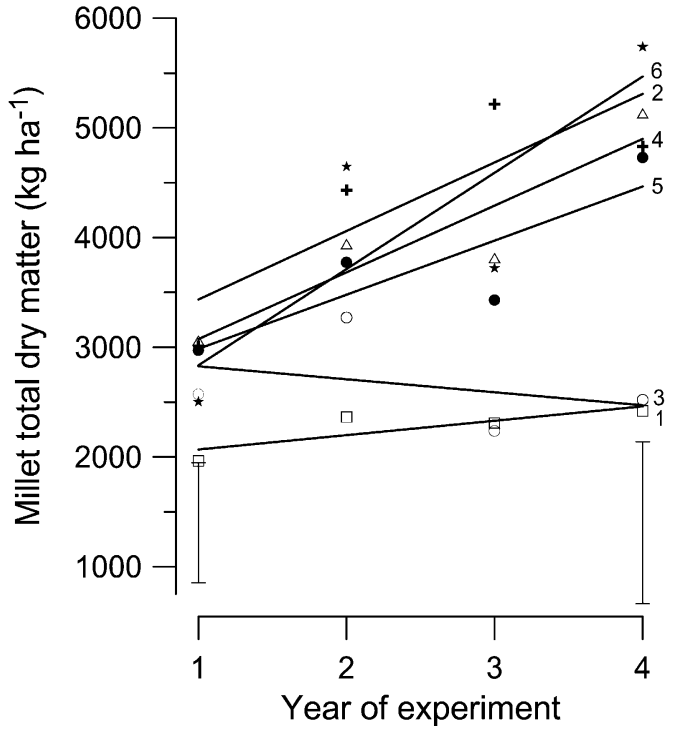

Fig. 3. Millet total dry matter at Kara Bedji, Niger averaged for nitrogen applied at 0 and $60 \mathrm{~kg} \mathrm{~N} \mathrm{ha}^{-1} \mathrm{yr}^{-1}$. For explanation of symbols and numbers see Fig. 1.

and P. The application of SSP13 and of $4_{\text {placed }}$ combined with either TRockP39 or TRockP130 led to a millet TDM twice as high as that of the unfertilised control (Fig. 6). For all $\mathrm{P}$ treatments,

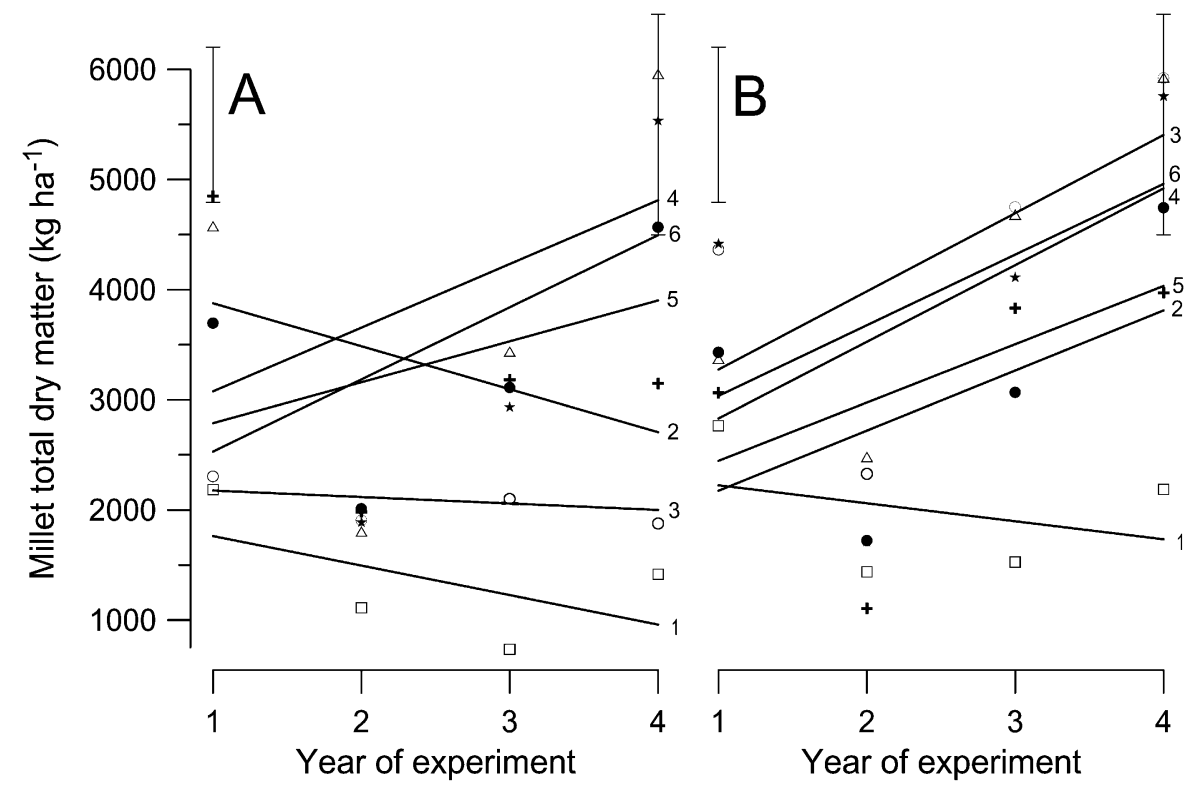

Fig. 4. Millet total dry matter at Goberi, Niger without (A) and with (B) nitrogen at $60 \mathrm{~kg} \mathrm{~N} \mathrm{ha}^{-1} \mathrm{yr}^{-1}$. For explanation of symbols and numbers see Fig. 1. 


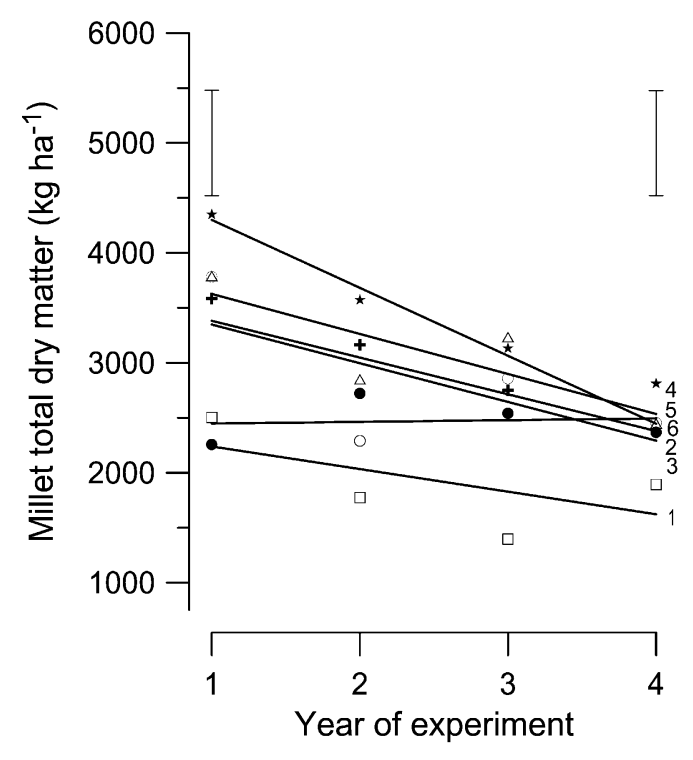

Fig. 5. Millet total dry matter at Gaya, Niger averaged for nitrogen applied at 0 and $60 \mathrm{~kg} \mathrm{~N} \mathrm{ha}^{-1} \mathrm{yr}^{-1}$. For explanation of symbols and numbers see Fig. 1.

regression slopes tended to be negative but these slopes were only significant $(P<0.01)$ for the two control treatments without $\mathrm{P}$, continuous SSP13 and TRockP39.
3.1.2.4. Phosphorus application in the Guinean zone. At Koukombo, maize TDM production in continuous control plots remained at a low but constant level throughout the duration of the experiment but increased significantly in rotation plots and with $\mathrm{N}$ application. Also, $\mathrm{P}$ response strongly depended on $\mathrm{N}$ application. In continuous maize plots without $\mathrm{N}$, time trends in the fourth year indicated significant increases in TDM compared to the control only for $\mathrm{P}$ placement, TRockP39 and TRockP39 $+\mathrm{P}_{\text {placed }}$ (Fig. 7A). In rotation plots, significant TDM increases compared to the control were noted only for TRockP39 $+\mathrm{P} 4$ placed (Fig. 7B). With $\mathrm{N}$ application, maize TDM at the end of the experiment was clearly superior for SSP13 and TRockP39+ P4 $4_{\text {placed, }}$, regardless of cropping system (Fig. 7C and D). Initially, $\mathrm{P}$ placement alone was overall more effective without $\mathrm{N}$ application.

At Kaboli, P effects on maize TDM depended even more strongly on $\mathrm{N}$ application than at Koukombo. Trend lines of $\mathrm{P}$ treatments did not show any timerelated TDM increase without $\mathrm{N}$ and none of the slopes was significantly different from the unfertilised control or from zero (Fig. 8A and B). With $\mathrm{N}$ application, TDM yield in the control treatment significantly increased over time for rotation but not for continuous maize. In continuous $\mathrm{N}$-fertilised maize, significant

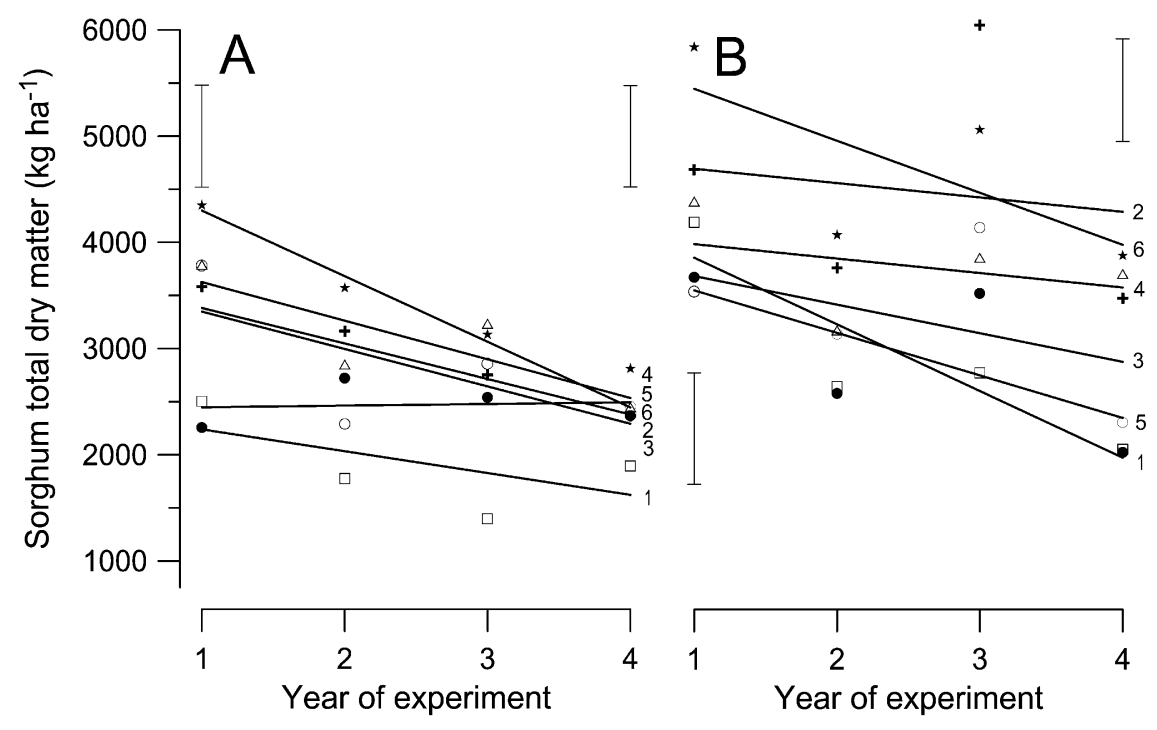

Fig. 6. Total dry matter of continuous sorghum (A) and sorghum after groundnut (B) at Fada, Burkina Faso averaged for nitrogen applied at 0 and $60 \mathrm{~kg} \mathrm{~N} \mathrm{ha}^{-1} \mathrm{yr}^{-1}$. For explanation of symbols and numbers see Fig. 1. 

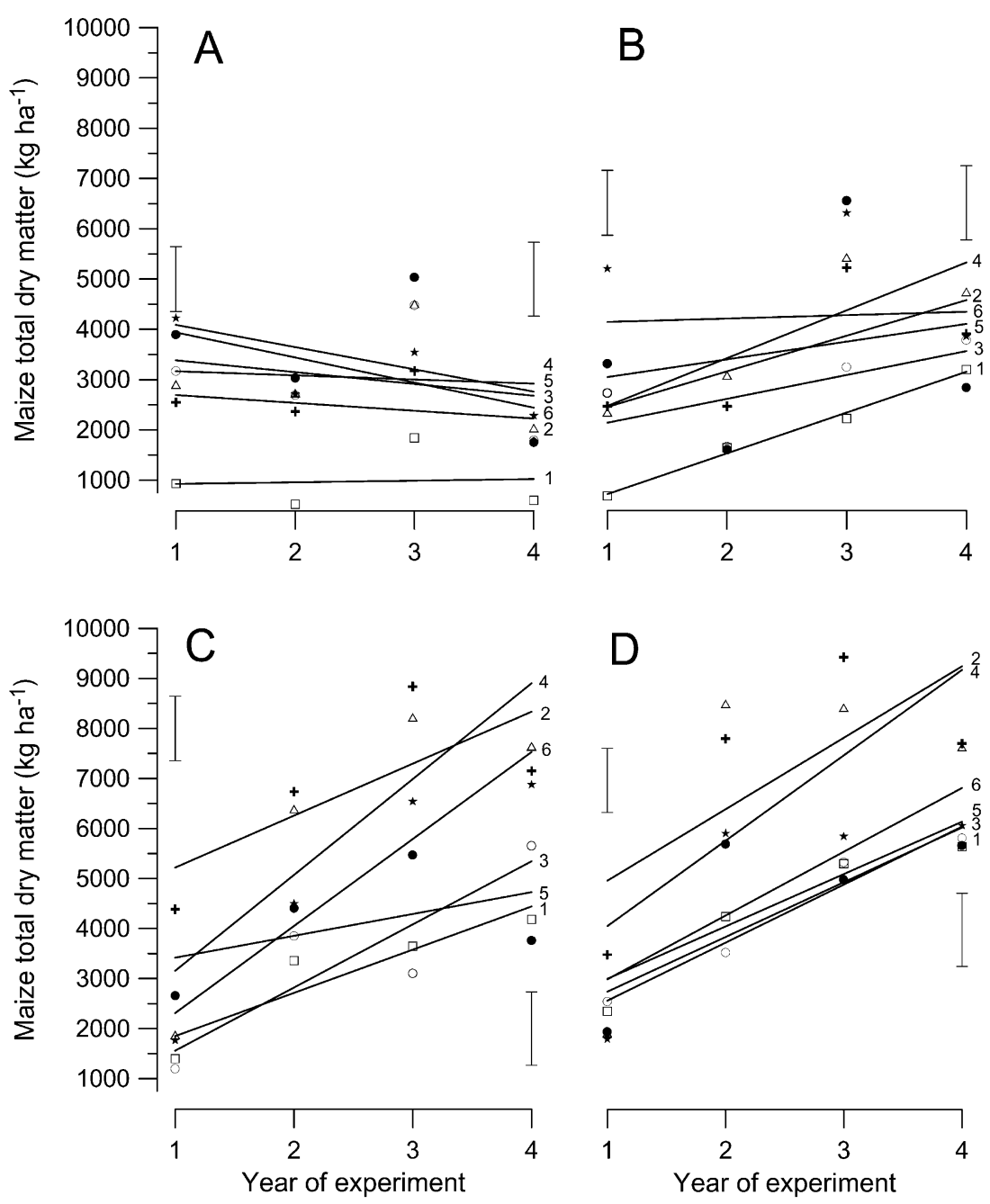

Fig. 7. Total dry matter of continuous maize (A) and maize after groundnut (B) without nitrogen (N) application and continuous maize (C) and maize after groundnut (D) with $\mathrm{N}$ at $60 \mathrm{~kg} \mathrm{ha}^{-1} \mathrm{yr}^{-1}$ at Koukombo, Togo. For explanation of symbols and numbers see Fig. 1.

time-depended increases in TDM were noted for P placement in combination with TRockP39 and TRockP130, but $\mathrm{P}$ response was much larger and statistically significant for all $\mathrm{P}$ treatments in rotation plots with $\mathrm{N}$ application (Fig. 8C and D).

\subsection{On-farm testing of $P$ placement}

In 1998 millet yields in $\mathrm{P} 4$ placed plots were, except for two fields, consistently larger than unfertilised control yields, which ranged between 0 and $1030 \mathrm{~kg} \mathrm{ha}^{-1}$. The average TDM yield in $\mathrm{P}_{\text {placed }}$ plots was $672 \mathrm{~kg} \mathrm{ha}^{-1}$, which was $120 \%$ higher than the average in P0 plots. This result was confirmed by the second set of on-farm tests in 1999 which showed average yield increases of $118 \%$ for NPK and of $116 \%$ for DAP (Fig. 9A and B).

There was a marked response of the difference in net return (DIFF) to the fertility score (MEAN; Fig. 10A). Only for very low productivity scores was the risk of $\mathrm{P} 0$ slightly lower than that of $\mathrm{P} 4_{\text {placed }}$, but in those cases the risks were not significantly different from each other. With increasing soil productivity, $\mathrm{P} 4_{\text {placed }}$ increasingly outperformed P0. That 

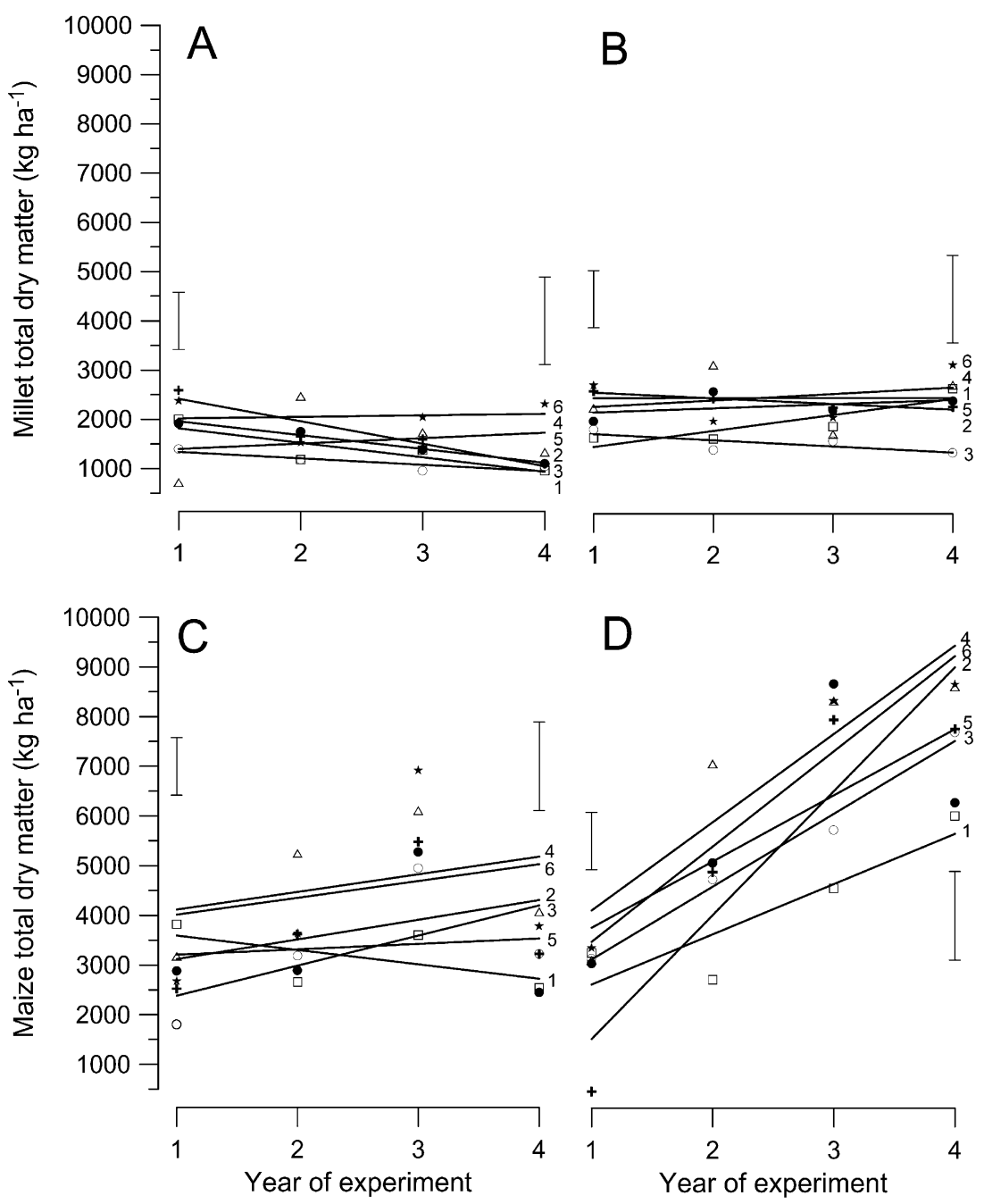

Fig. 8. Total dry matter of continuous maize (A) and maize after groundnut (B) without nitrogen (N) application and continuous maize (C) and maize after groundnut (D) with $\mathrm{N}$ at $60 \mathrm{~kg} \mathrm{ha}^{-1} \mathrm{yr}^{-1}$ at Kaboli, Togo. For explanation of symbols and numbers see Fig. 1.

is, for larger MEAN values the probability of $\mathrm{P} 0$ to outperform $\mathrm{P}_{\text {placed }}$ was significantly lower than $50 \%$.

\section{Discussion}

\subsection{Treatment effects on legumes and legume rotation effects on cereals}

While the limited $\mathrm{N}$ effects on legume growth in this study may be explained by the overall low yield levels and the legumes' $\mathrm{N}_{2}$ fixation capacity, the only minor effects of $\mathrm{P}$ application on both cowpea and groundnut growth over time were particularly surprising in view of previous findings which showed significant $\mathrm{N}$ and $\mathrm{P}$ effects for cowpea (Bationo, unpublished data; Bationo and Ntare, 2000) and $\mathrm{N}$ effects for groundnut at Sadoré (Hafner et al., 1992). For P application in groundnut, Rebafka et al. (1993b) have shown that on acid sandy Sahelian soils SSP application can be ineffective due to a suppression of molybdenum uptake by sulfate ions in the soil solution. However, this would not explain the lacking response of cowpea to TRockP at Gaya with its low $\mathrm{pH}$ and high rainfall. 

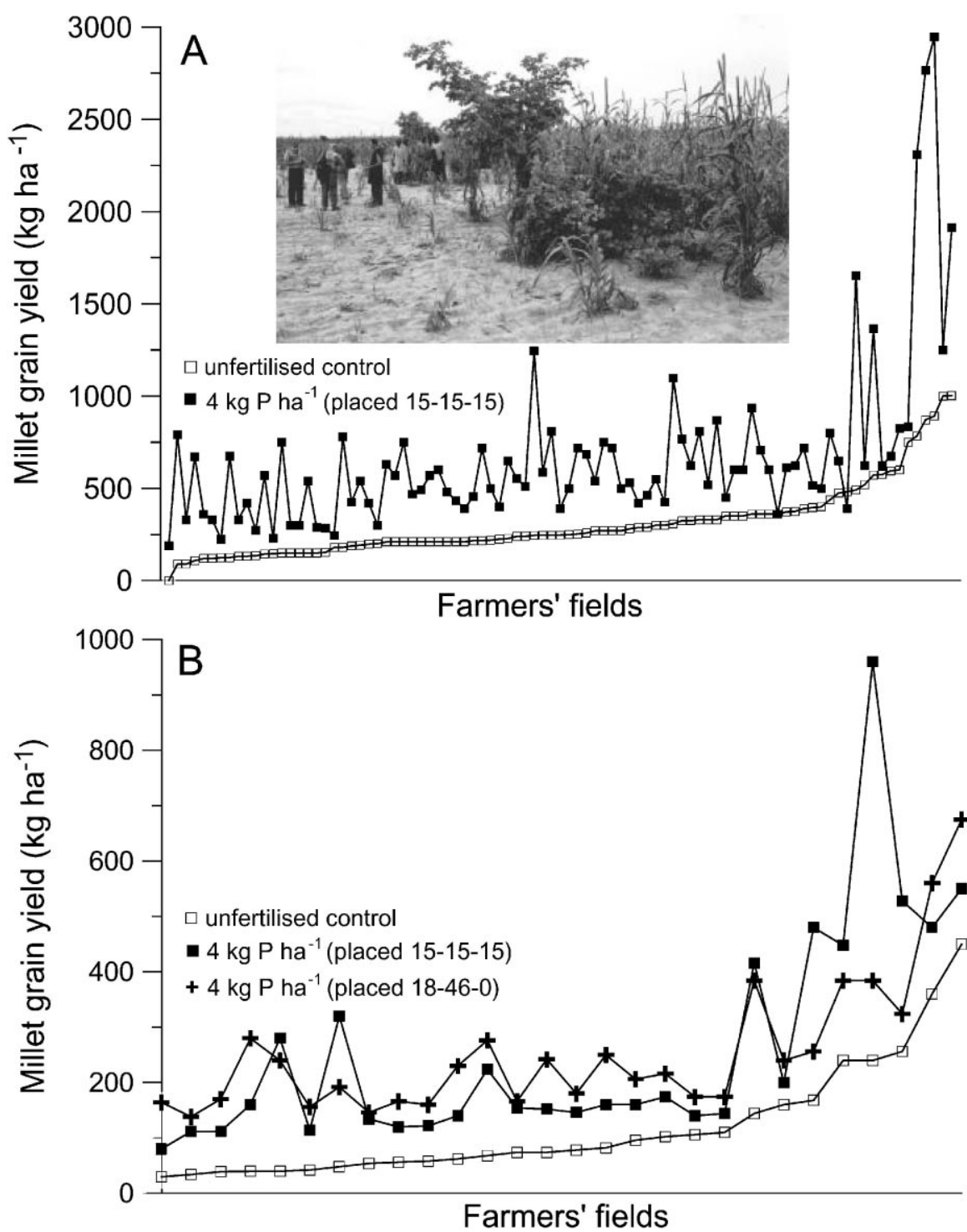

Fig. 9. Effects of hill-placed application of $4 \mathrm{~kg} \mathrm{P} \mathrm{ha}^{-1}$ as NPK (15-15-15) or DAP (18-46-0) at sowing on millet grain yield in farmers' fields in Niger during 1998 (A) and 1999 (B). Yield data were sorted according to their magnitude in unfertilised control plots. The photograph in A shows a farmer's field in Maradi with the unfertilised control plot (left) and a neighbouring plot with P placement to millet (right). Millet grain yield data of 1999 were kindly provided by D. Marchal, FAO, Niamey, Niger.

In this study significant legume rotation effects on cereal TDM time trends were only observed for groundnut which is in contrast to data from Bationo and Ntare (2000) collected over 5 years at three sites in Niger. The reported over 10 -fold greater atmospheric $\mathrm{N}_{2}$ fixation of groundnut compared to cowpea (Peoples and Craswell, 1992) may explain this legume-specific difference in rotation effects assuming that rotation effects on these sites with higher rainfall were caused by improved $\mathrm{N}$ availability. Other reasons could be species-dependent changes in $\mathrm{pH}$ or ligand exchanging exudates in the rhizosphere soil of legumes which are known to affect P availability (Ae and Otani, 1997; Alvey et al., 


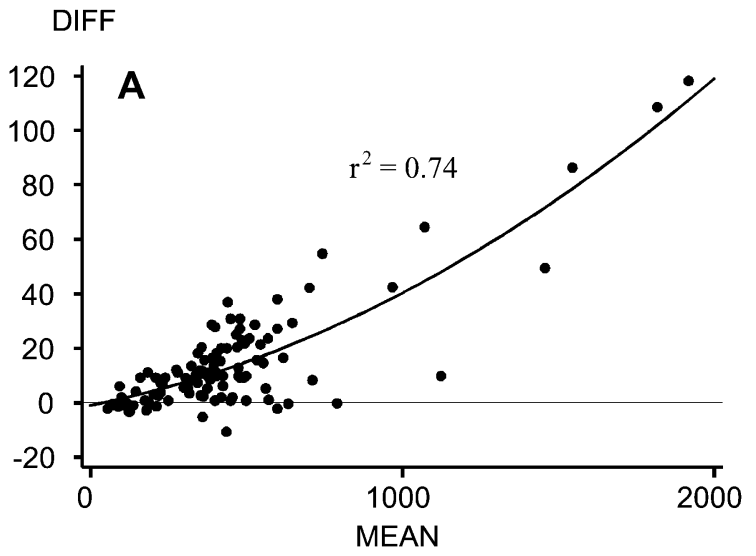

RISK

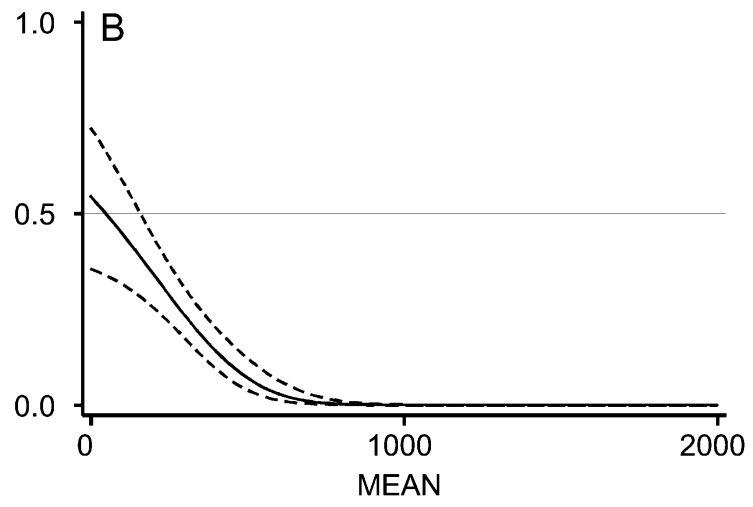

Fig. 10. (A) Quadratic regression between the difference in net returns (DIFF in $1000 \mathrm{FCFA} \mathrm{ha}^{-1}$ ) for hill-placed application in millet of $4 \mathrm{~kg} \mathrm{Pha}^{-1}$ (P4 placed $)$ as NPK compared to the unfertilised control treatment (P0) and the soil productivity index (MEAN), calculated as $\left[\frac{1}{2}\left(\mathrm{P} 4_{\text {placed }}+\mathrm{P} 0\right)\right]$, for each of the 91 Nigerien farms in 1998. (B) Risk plot depicting the probability that net returns of $\mathrm{P} 4_{\text {placed }}$ are smaller than those of the unfertilised control treatment $\mathrm{P} 0$ as a function of the soil productivity index. Dotted lines indicate the $95 \%$ confidence limits.

2001; Bagayoko et al., 2000a; Ohwaki and Hirata, 1992).

\subsection{Cereals}

\subsubsection{Nitrogen versus phosphorus effects}

With both cropping systems and regardless of $\mathrm{N}$ application, cereal TDM trends without $\mathrm{P}$ declined at all Sudano-Sahelian sites except for Banizoumbou and Kara Bedji. This suggests that limited $\mathrm{N}$ availability may not be the primary cause for the often observed yield decline in continuous cereal cropping of the drier areas of sub-Saharan West Africa and the subsequent need for extended fallow periods. In the Guinean zone of Koukombo and Kaboli, however, N was clearly the most important growth limiting factor. Phosphorus effects became only significant after $\mathrm{N}$ constraints had been removed (Figs. 7 and 8). At a more general level, these results confirm the findings of Poulain et al. (1974) and support the data of Uyovbisere and Lombim (1991), Halm and Dartey (1991), Jallah et al. (1991) and Maduakor (1991). In combination these authors provide consistent evidence that the role of $\mathrm{N}$ versus $\mathrm{P}$ as primary limiting factors for crop growth increases with rainfall and TDM production from the semi-arid Sahel to the subhumid Guinean zone of West Africa.

\subsubsection{Soluble P versus RockP}

Without N, trend lines showed larger cereal TDM production for annual SSP application than for TRockP, regardless of the cropping system, consistently over time and for all sites except for continuous maize at Koukombo. The size of the differences between these two $\mathrm{P}$ fertiliser treatments was strongly site-specific. At Kara Bedji, TRockP39 effects were independent of $\mathrm{N}$ application and negligible compared to the $116 \%$ final TDM increase for SSP (Fig. 3). At Goberi, however, the relative advantage of TRockP39 compared to SSP strongly depended on $\mathrm{N}$ application. With the application of $60 \mathrm{~kg} \mathrm{~N} \mathrm{ha}^{-1}$, in the fourth year TRockP39 was twice as effective as SSP in increasing TDM above control without $\mathrm{P}$, whereas without N, SSP was more effective (Fig. 4). The dependence of relative TRockP39 effects on N application is hard to explain but may be related to a more vigorous root growth and thus improved contact between roots and RockP-P in N-fertilised millet. The data also support the results of Bationo et al. (1990) who showed an overall similar effectiveness for TRockP and SSP for this strongly acid site. At Gaya, a site with low $\mathrm{pH}$ and comparatively larger rainfall, TRockP and SSP affected millet TDM similarly throughout the duration of the experiment (Fig. 5, Table 1). At Fada, however, a site with similar annual rainfall and clay content to Gaya but with much higher $\mathrm{pH}$, SSP-induced increases in rotation sorghum TDM were twice as large as for TRockP39, irrespective of N application. The similar relative effects of TRockP 
and SSP observed at the two Guinean sites with their high $\mathrm{pH}$, associated cation exchange capacity and base saturation underline the previously reported predominant importance of soil parameters compared to rainfall in governing $\mathrm{P}$ availability from RockP to cereals (Sinaj et al., 2001).

Overall, these results may contribute to ending the decades-old often rather ideological discussion about the advantages and disadvantages of widespread RockP application to counteract $\mathrm{P}$ depletion in subSaharan West Africa. If $\mathrm{P}$ costs are to be carried by farmers and not the general public, cost-effectiveness at the farm-level must be the criterion of choice. The results suggest that locally available high quality RockP can only be an alternative to SSP at the farmers' level if it is much cheaper, properly conditioned to avoid negative farmer reactions to its powdery nature and most of all if its application is restricted to well-defined zones with low $\mathrm{pH}$ and high rainfall.

\subsubsection{P placement effects on-station and on-farm}

Compared to the control, time trends for $\mathrm{P} 4_{\text {placed }}$ application alone indicated final cereal TDM increases between 50 and $220 \%$ across all sites, except for Koukombo and Kaboli, that were rather independent of $\mathrm{N}$ and cropping system. At the latter sites the low effectiveness of $\mathrm{P} 4$ placed was likely due to the much higher planting densities for maize and the overall higher TDM which caused P application at the NPK rate applied to be only a fraction of total plant $\mathrm{P}$ uptake. The fact that the combination of TRockP at 39 and $130 \mathrm{~kg} \mathrm{Pha}^{-1}$ with $\mathrm{P}_{\text {placed }}$ led to large additive effects across all sites and was rather independent of $\mathrm{N}$ and cropping system points to the complementary nature of both forms of $\mathrm{P}$ application. While RockP application affects the long-term $\mathrm{P}$ status of the soil (Sinaj et al., 2001), the small amount of readily available $\mathrm{P}$ in the $\mathrm{P} 4_{\text {placed }}$ treatment likely stimulated seedling growth and subsequently improved overall $\mathrm{P}$ uptake through better developed cereal roots. It was particularly interesting that at the same rate of applied $\mathrm{P}$, grain yield increases with placed mineral fertiliser were similar, irrespective of its type. Placement of NPK contained $9.2 \mathrm{~kg} \mathrm{~N}$ ha $^{-1}$, of which about half was in the form of ammonium $\left(\mathrm{NH}_{4}{ }^{+}\right)$, but with DAP, only $3.6 \mathrm{~kg} \mathrm{~N}^{-1}$ was applied, however, entirely as $\mathrm{NH}_{4}{ }^{+}$. This indicates that the relatively small but early applied $\mathrm{NH}_{4}{ }^{+}$component in the NPK fertiliser may have substantially enhanced the $\mathrm{P}$ effects on cereal seedlings by directly stimulating root growth (Oikeh et al., 1999; Strasser and Werner, 1995). The choice of whether to apply $\mathrm{P} 4_{\text {placed }}$ alone or in combination with RockP to enhance the effectiveness of the latter will largely depend on site-specific soil $\mathrm{pH}$ conditions and the price of RockP. The on-farm data of this study show that, except for the most marginal soils, $\mathrm{P} 4$ placed alone is a yield enhancing strategy of low economic risk (Fig. 10) and may thus help to reverse declining yield trends across a wide range of agro-ecological conditions. However, as a note of caution, it should be mentioned that the $0.9 \mathrm{~g} \mathrm{~N}$ applied together with $0.4 \mathrm{~g}$ $\mathrm{P}$ in NPK to each planting hill constitutes only between 10 and $20 \%$ of a millet plant's total $\mathrm{N}$ uptake. At present, it remains unclear what role free-living or rhizosphere-bound $\mathrm{N}_{2}$-fixing bacteria play within the $\mathrm{N}$ balance of the predominantly cereal-based cropping systems of sub-Saharan West Africa and how they are affected by P-induced improved plant growth and likely higher exudation of C-sources in the rhizosphere (Hafner et al., 1993). Therefore, the $\mathrm{P}_{\text {placed }^{-}}$ induced large increases in cereal TDM should only be regarded as a first step to a more integrated effort to restore soil fertility and associated social welfare of millions of peasants in this region by targeted inputs of mineral fertilisers and careful prevention of nutrient losses within the predominantly agro-pastoral landuse systems.

\section{Acknowledgements}

The authors are grateful to ICRISAT Sahelian Centre (Niger), INERA (Burkina Faso) and IFDCAfrica (Togo) for logistic support, to M. Bagayoko and $\mathrm{K}$. Dossa for their cooperation during data collection and to the Deutsche Forschungsgemeinschaft (DFG) for funding within the SFB308 and an additional grant.

\section{References}

Ae, N., Otani, T., 1997. The role of cell wall components from groundnut roots in solubilizing sparingly soluble phosphorus in low fertility soils. In: Ando, T., et al. (Eds.), Plant Nutrition — for Sustainable Food Production and Environment. Developments in Plant and Soil Sciences. Kluwer Academic Publishers, Dordrecht, The Netherlands, pp. 309-314. 
Alvey, S., Bagayoko, M., Neumann, G., Buerkert, A., 2001. Cereal/ legume rotations affect chemical properties and biological activities in two West African soils. Plant Soil, 231, 45-54.

Bagayoko, M., Alvey, S., Buerkert, A., Neumann, G., 2000a. Rootinduced increases in $\mathrm{pH}$ and nutrient availability to field-grown cereals and legumes on acid sandy soils of West Africa. Plant Soil 225, 117-127.

Bagayoko, M., Buerkert, A., Lung, G., Bationo, A., Römheld, V., 2000b. Cereal/legume rotation effects on cereal growth in Sudano-Sahelian West Africa: soil mineral nitrogen, mycorrhizae and nematodes. Plant Soil 218, 103-116.

Bationo, A., Ntare, B.R., 2000. Rotational and nitrogen fertiliser effects on pearl millet, cowpea and groundnut yield and soil chemical properties in a sandy soil in the semi-arid tropics, West Africa. J. Agric. Sci. 134, 277-284.

Bationo, A., Chien, S.H., Henao, J., Christianson, B.C., Mokwunye, A.U., 1990. Agronomic evaluation of two unacidulated and partially acidulated phosphate rocks indigenous to Niger. Soil Sci. Soc. Am. J. 54, 1772-1777.

Bationo, A., Christianson, B.C., Baethgen, W.E., Mokwunye, A.U., 1992. A farm-level evaluation of nitrogen and phosphorus fertiliser use and planting density for pearl millet production in Niger. Fert. Res. 31, 175-184.

Bationo, A., Christianson, B.C., Klaij, M.C., 1993. The effect of crop residue and fertiliser use on pearl millet yields in Niger. Fert. Res. 34, 251-258.

Bationo, A., Lompo, F., Koala, S., 1998a. Research on nutrient flows and balances in West Africa: state-of-the art. Agric. Ecosyst. Environ. 71, 19-35.

Bationo, A., Ndjeunga, J., Bielders, C., Prabhakar, V.R., Buerkert, A., Koala, S., 1998b. Soil fertility restoration options to enhance pearl millet productivity on sandy Sahelian soils in south-west Niger. In: Lawrence, P., Renard, G., von Oppen, M. (Eds.), Proceedings of an International Workshop on the Evaluation of Technical and Institutional Options for Small Farmers in West Africa, University of Hohenheim, Stuttgart, Germany, April 21-22, 1998. Margraf Verlag, Weikersheim, Germany, pp. 93-104.

Buerkert, A., Hiernaux, P., 1998. Nutrients in the West African Sudano-Sahelian zone: losses, transfers and role of external inputs. J. Plant Nutr. Soil Sci. 161, 365-383.

Buerkert, A., Bationo, A., Dossa, K., 2000. Mechanisms of residue mulch induced cereal growth increases in West Africa. Soil Sci. Soc. Am. J. 64, 346-358.

Christianson, B.C., Bationo, A., Baethgen, W.E., 1990. The effect of soil tillage and fertiliser use on pearl millet yields in Niger. Plant Soil 123, 51-58.

Diggle, P.J., Liang, K.-Y., Zeger, S.L., 1994. Analysis of Longitudinal Data. Clarendon Press, London.

Hafner, H., Ndunguru, B.J., Bationo, A., Marschner, H., 1992. Effect of nitrogen, phosphorus and molybdenum application on growth and symbiotic $\mathrm{N}_{2}$ fixation of groundnut in an acid sandy soil in Niger. Fert. Res. 31, 69-77.

Hafner, H., Bley, J., Bationo, A., Martin, P., Marschner, H., 1993. Long-term nitrogen balance for pearl millet (Pennisetum glaucum L.) in an acid sandy soil of Niger. J. Plant Nutr. Soil Sci. 156, 169-176.
Halm, A.T., Dartey, K., 1991. Efficient fertiliser use for increased crop production: the Ghana experience. In: Mokwunye, A.U. (Ed.), Alleviating Soil Fertility Constraints to Increased Crop Production in West Africa. Kluwer Academic Publishers, Dordrecht, The Netherlands, pp. 139-147.

Jallah, J.K., Mulbah, C.K., Kiazolu, J.S., Frank, K., Morris, M.Z., 1991. Efficient fertiliser use for increased crop production: the Liberia experience. Fert. Res. 29, 55-64.

Maduakor, H.O., 1991. Efficient fertiliser use for increased crop production: the humid Nigeria experience. Fert. Res. 29, 65-79.

McClellan, G.H., Notholt, A.J.G., 1986. Phosphate deposits of tropical sub-Saharan Africa. In: Mokwunye, A.U., Vlek, P.L.G. (Eds.), Management of Nitrogen and Phosphorus Fertilisers of Sub-Saharan Africa. Martinus Nijhoff, Dordrecht, The Netherlands, pp. 173-223.

McIntire, J., 1986. Constraints of fertiliser use in sub-Saharan Africa. In: Mokwunye, A.U., Vlek, P.L.G. (Eds.), Management of Nitrogen and Phosphorus Fertilisers of Sub-Saharan Africa. Martinus Nijhoff, Dordrecht, The Netherlands, pp. 37-57.

Nelder, J.A., 1994. The statistics of linear models: back to basics. Stat. Comput. 4, 221-234.

Ohwaki, Y., Hirata, H., 1992. Differences in carboxylic acid exudation among P-starved leguminous crops in relation to carboxylic acid contents in plant tissues and phospholipid levels in roots. Soil Sci. Plant Nutr. 38, 235-243.

Oikeh, S.O., Kling, J.G., Horst, W.J., Chude, V.O., Carsky, R.J., 1999. Growth and distribution of maize roots under nitrogen fertilization in plinthite soil. Field Crop. Res. 62, 1-13.

Peoples, M.B., Craswell, E.T., 1992. Biological nitrogen fixation: investments, expectations and actual contributions to agriculture. Plant Soil 141, 13-39.

Piepho, H.-P., 2000a. Zur Durchführung multipler Vergleiche in Nicht-Standardsituationen. Zeitschrift für Agrarinformatik 8, $16-20$.

Piepho, H.-P., 2000b. Multiple treatment comparisons in linear models when the standard error of a difference is not constant. Biometr. J. 42, 823-835.

Piepho, H.-P., 2000c. Exact confidence limits for covariatedependent risk in cultivar trials. J. Agric. Biol. Environ. Stat. $5,202-213$.

Poulain, J.F., Doumbia, A., Franc, M., Jenny, F., Pieri, C., Thibout, F., Traoré, M.-F., 1974. Amelioration de la fertilité des sols agricoles du Mali. Bilan de treize annees de travaux (19621974). L'Agronomie Tropicale 31, 403-416.

Rebafka, F.-P., Bationo, A., Marschner, H., 1993a. Phosphorus seed coating increases $\mathrm{P}$ uptake, early growth and yield of pearl millet (Pennisetum glaucum (L.) R. Br.) grown on an acid sandy soil in Niger, West Africa. Fert. Res. 35, 151-160.

Rebafka, F.-P., Bationo, A., Marschner, H., 1993b. Single superphosphate depresses molybdenum uptake and limits yield response to phosphorus in groundnut (Arachis hypogaea L.) grown on an acid sandy soil in Niger, West Africa. Fert. Res. 34, 233-242.

Roesch, M., Pichot, J., 1985. Use of Tahoua rock phosphate: initial basal dressing and maintenance applications in the sandy soils of Niger. L'Agronomie Tropicale 40, 89-97. 
SAS Institute, 1990. SAS/STAT User's Guide, Version 6, 4th Edition, Vol. 2. SAS Institute, Cary, NC.

Sinaj, S., Buerkert, A., EI-Hajj, G., Bationo, A., Traoré, H., Frossard, E., 2001. Effects of fertility management strategies on phosphorus bioavailability in four West African soils. Plant Soil $233,71-83$.

Sissingh, H.A., 1971. Analytical technique of the Pw method used for the assessment of the phosphate status of arable soils in the Netherlands. Plant Soil 34, 483-486.

Stoorvogel, J.J., Smaling, E.M.A., 1994. Assessment of soil nutrient depletion in sub-Saharan Africa: 1983-2000, Vol. 1, Main Report. The Winand Staring Centre, Wageningen, The Netherlands, 137 pp.
Strasser, B., Werner, W., 1995. Einfluß von Form und Plazierung der N- und P-Düngung auf Wurzelentwicklung, PhosphatAufnahme und Wachstum von Sonnenblumen (Helianthus annuus) und Zuckerhirsen (Sorghum bicolor). J. Agron. Crop Sci. 175, 157-165.

Uyovbisere, E.O., Lombim, G., 1991. Efficient fertiliser use for increased crop production: the sub-humid Nigeria experience. Fert. Res. 29, 81-94.

van Reuler, H., Prins, W.H., 1993. The role of plant nutrients for sustainable food crop production in sub-Saharan Africa. Vereniging van Kunstmest Producenten, Leidschendam, The Netherlands, 259 pp. 